\title{
Para pensar o futuro
}

Thinking of the future

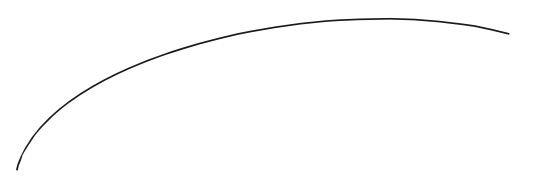

Basta olhar o último ano da Revista Brasileira de Geriatria e Gerontologia para se observar uma importante mudança. Os artigos chegam de pesquisadores de todas as regiões brasileiras e os temas são cada vez mais diversos. Este sempre foi o objetivo da RBGG, pois o campo de conhecimento da área do envelhecimento humano é extremamente extenso, e para darmos conta das demandas presentes torna-se necessária uma visão ampliada e diferenciada do tema.

As páginas da RBGG compuseram, ao longo deste ano, um mosaico de opiniões, propostas, dados, análises e diagnósticos sobre um tema que é muito caro a cada um de nós - quando nada, porque esperamos todos viver longamente, com a melhor saúde, a máxima disposição, em plena atividade, confortavelmente amparados pela família, pelas instituições e pela sociedade.

O envelhecimento é inevitável. Suas consequências físicas também - ainda que hoje contemos com muito mais recursos e tecnologia para amenizar os déficits funcionais. Mas é possível e desejável eliminar o preconceito, desfazer estereótipos, ampliar a autonomia e o espaço de participação do idoso como cidadão, contribuinte, profissional e ser humano com direitos, deveres, conquistas e superações. Alguém capaz de amar e ser amado, de trabalhar, contribuir, ter ideias, gerar renda, ensinar e - como não? - aprender.

Ao contrário do que diz o lugar-comum, a vida não começa aos 40, tampouco se encerra aos 60 ou 70. Vemos hoje, segundo nos mostram diversas análises demográficas, que vem ocorrendo um envelhecimento progressivo da população. Precisamos, portanto, nos antecipar aos efeitos desse fenômeno e começar a discutir seriamente as questões que perpassam o universo da terceira idade.

Um novo olhar para a terceira idade é, portanto, mais do que necessário. E por este motivo, na condição de editor da Revista, me atrevo a sugerir novos campos para serem discutidos e pesquisados entre os especialistas. A proposta lançada é a seguinte: a primeira idade é do aprendizado; a segunda, dos resultados; e a terceira ficou injustamente estigmatizada como uma etapa de improdutividade e decadência. Mas isso pode mudar. E o voluntariado, por exemplo, pode ser uma prática transformadora nesse cenário. Que tal entender melhor para aqueles que ingressarem na terceira idade dividirem o tempo entre o trabalho voluntário, o lazer e o foco em novos interesses, conhecimentos e habilidades. Afinal, por que não?

O trabalho voluntário é uma grande alternativa que se abre para o recém-aposentado; essa participação, além de ampliar os espaços de cidadania e representatividade da população idosa, torna o envelhecimento mais equilibrado, harmonioso e saudável. O idoso se sente mais disposto, com mais perspectivas e sentido de vida, abandonando, assim, aquilo que até pouco tempo antes era comum ver na população idosa: o isolamento, uma imagem negativa de si mesmo - ou uma imagem negativa que a sociedade fazia dele. 
As possibilidades de empreendedorismo na terceira idade se ampliam a cada dia. Dados recentes demonstram que aumenta progressivamente o número de negócios criados e administrados por pessoas com mais de 60 anos. Gente que troca a aposentadoria por uma revisão da própria vida, que conduz a um olhar voltado para um novo horizonte profissional - às vezes, sem as "amarras" $\mathrm{da}$ atividades anterior, às vezes apenas descortinando novos ou adormecidos interesses.

A aposentadoria, como vemos, pode ser uma fase ativa, ao contrário do que propagam os estereótipos. A vice-diretora da Universidade Aberta da Terceira Idade (UnATI), professora Célia Pereira Caldas, já disse isto. Para ela, "somos nós que atribuímos o significado que esta fase da vida terá. E é necessária uma preparação para que o aposentado aproveite ao máximo esse período, investindo em sua saúde física e mental, valorizando o autocuidado e o aproveitamento máximo de suas potencialidades e seus objetivos. $\mathrm{O}$ aumento da expectativa de vida da população brasileira estabelece a necessidade de refletir: é preciso dar um novo significado a essa etapa da existência humana.

São muitos os cenários, e o espírito empreendedor, como vemos, é algo que não morre com a idade. Os temores de quem precisa dar o primeiro passo são naturais, mas superáveis. $\mathrm{O}$ empreendedorismo abre a perspectiva de uma gama de serviços e oportunidades para as pessoas acima de 60 anos. E, mais uma vez, a palavra de ordem é planejamento. Como em qualquer idade, é preciso se preparar, fazer um bom plano de negócios, conhecer o mercado em que deseja atuar. $\mathrm{O}$ diferencial será uma maior disponibilidade de tempo para aprender e uma sabedoria que só a idade confere.

Portanto, ao abrirmos o leque de temas, também devemos apontar para as vantagens de contar com essa vivência e esse conhecimento acumulado. Continuar a aprender e continuar a ser uma pessoa ativa, sim, mas sem abrir mão da qualidade. Mas o que se quer dizer exatamente quando se fala em qualidade de vida? Destrinchar esse conceito que, a alguns olhos, pode parecer demasiadamente subjetivo, pode ser uma excelente linha de reflexão. Há quem associe qualidade de vida a bens materiais. E há mesmo um espaço importante a ser preenchido com programas voltados especificamente para o profissional da terceira idade, aliados a ações de responsabilidade social empresarial. Essa iniciativa apresenta grandes vantagens tanto para os empregados quanto para as próprias companhias.

Diante desse quadro, surge uma questão-chave: o que é preciso fazer para que o idoso usufrua os anos a mais de vida de forma plena e saudável? O ponto de partida são as políticas públicas para a terceira idade, com serviços de qualidade, ética, humanismo e, sobretudo, criatividade para encontrar soluções. Soluções que favoreçam o cuidado com a saúde, a manutenção de um bom padrão de vida, o exercício pleno da sua cidadania e possibilidade de geração de renda.

As questões que envolvem o envelhecimento humano são um tema atual e que vem ganhando cada vez mais importância no Brasil e em todo o mundo. Várias possibilidades estão presentes para linhas criativas e inovadoras de pesquisas. Leia, comente, repercuta, participe: é o convite que deixamos a você.

Renato Veras

Editor da RBGG 